\title{
Synthesis and Characterization of IZO Composite Prepared by Sol-Gel Method
}

\author{
Raghad J. Halbos, Sariya Al-Algawi and Rashed T. Rasheed \\ Department of Applied Science, University of Technology, Baghdad-Iraq.
}

\begin{abstract}
Indium oxide and indium zinc oxide composite (IZO) were prepared by sol-gel method and deposited on quartz substrate by dip coating technique. Two annealing temperatures (200 and $400^{\circ} \mathrm{C}$ ) and compositions were done. The structure and surface morphology of particles were characterized by X-ray diffraction (XRD), Atomic Force Microscope (AFM), FT-IR measurements. The XRD and AFM indicate decreasing in the particle size and improve of optical and electrical properties of composite with increasing of zinc oxide addition. The results of Hall measurements show that the $\mathrm{In}_{2} \mathrm{O}_{3}$ and its composite (IZO) have n-type.
\end{abstract}

Keywords: Indium oxide, zinc oxide, composite, sol-gel, XRD, AFM.

\section{Introduction}

Indium oxide $\left(\operatorname{In}_{2} \mathrm{O}_{3}\right)$ nanoparti-cles has unique characteristics such as good conductivity, high optical transmittance over the visible wavelength region, excellent adhesion to substrates and chemical stability and photochemical properties. Indium oxide is a wide band gap n-type semiconductor with direct band gaps of $3.75 \mathrm{eV}$ [1]. Composite films are thin films composed by combining two or more different substances having nano dimensional phase in order to control and develop new and enhanced properties and structures.

Transparent conducting oxide (TCO) films have been extensively researched for a variety of optoelectronic devices such as displays, solar cells, and low-windows [2, 3]. Among the TCO films, ITO (Sn-doped indium oxide) is well known as the most commonly used materials with low resistivity and high optical transparency in the visible region However, there is a growing demand for less expensive materials (e.g., $\mathrm{ZnO}, \mathrm{In}_{2} \mathrm{O}_{3}-\mathrm{ZnO}$, and $\mathrm{SnO}_{2}$ ) because of the high cost of ITO films. In particular, the $\mathrm{In}_{2} \mathrm{O}_{3}-\mathrm{ZnO}$ system has attracted considerable interest. Moriga et al. studied the phase relations and physical properties of homologous compounds in a bulk $\mathrm{In}_{2} \mathrm{O}_{3}-\mathrm{ZnO}$ system [4]. $\mathrm{In}_{2} \mathrm{O}_{3}-\mathrm{ZnO}$ thin films have been prepared by metal organic chemical vapor deposition [5], sputtering [6, 7], and laser deposition [8], thin films prepared by sol - gel method are rare. The sol -gel method offers many advantages such as highly homogeneous thin films, large area coating, absence of the need for vacuum, low cost, and high flexibility [9]. In this paper, by using this sol - gel technology, $\operatorname{In}_{2} \mathrm{O}_{3}-\mathrm{ZnO}$ thin films were fabricated and their electrical and optical properties were investigated for several atomic ratios of $\mathrm{In}_{2} \mathrm{O}_{3}$ : $\mathrm{ZnO}$ (80:20 and 60:40 mole ratio).

\section{Experimental}

\subsection{Preparation of Indium Oxide particles:}

Indium oxide particles were synthesized by the sol-gel method. Indium nitrate $\left(\mathrm{In}\left(\mathrm{NO}_{3}\right)_{3} . \mathrm{H}_{2} \mathrm{O}\right)(0.3 \mathrm{M})$ dissolved in distilled water and the solution was stirred in glass beaker with the help of a magnetic stirrer at $25^{\circ} \mathrm{C}$ for 20 minute to ensure completely dissolved. Meanwhile, $0.6 \mathrm{M}$ of sodium hydroxide $(\mathrm{NaOH})$ was dissolved in distilled water in another glass beaker with the help of a magnetic stirrer at $25^{\circ} \mathrm{C}$ for 20 minute to ensure completely dissolved. The basic solution $(\mathrm{NaOH})$ was slowly added in drop by drop (3 drops in minute) to the $\mathrm{In}\left(\mathrm{NO}_{3}\right)_{3} \cdot \mathrm{H}_{2} \mathrm{O}$ solution under constant stirring until the $\mathrm{pH}$ equal 8 , and precipitation occurred. The precipitate washed with distilled water (about 5 times) and then with ethanol (2 times), and then the precipitate was dried in oven at $200^{\circ} \mathrm{C}$ for $90 \mathrm{~min}$ (white precipitate), and yellow precipitate convert when annealing at $400^{\circ} \mathrm{C}$.

The general reaction equations are:

1. $2 \mathrm{In}\left(\mathrm{NO}_{3}\right)_{3} \cdot \mathrm{H}_{2} \mathrm{O}+6 \mathrm{NaOH} \rightarrow 2 \mathrm{In}(\mathrm{OH})_{3}+$ $6 \mathrm{NaNO}_{3}+2 \mathrm{H}_{2} \mathrm{O}$

2. $2 \mathrm{In}(\mathrm{OH})_{3} \rightarrow \mathrm{In}_{2} \mathrm{O}_{3}+3 \mathrm{H}_{2} \mathrm{O}$

The overall equation is: $2 \mathrm{In}\left(\mathrm{NO}_{3}\right)_{3} \cdot \mathrm{H}_{2} \mathrm{O}+6 \mathrm{NaOH} \rightarrow \mathrm{In}_{2} \mathrm{O}_{3}+6 \mathrm{NaNO}_{3}$ $+5 \mathrm{H}_{2} \mathrm{O}$ 


\subsection{Preparation of $\mathrm{ZnO}$ particle:}

Zinc oxide particles which prepared also by the sol-gel method. Zinc chloride dissolved in distilled water $(0.74 \mathrm{M})$ and sodium hydroxide $(\mathrm{NaOH})(0.6 \mathrm{M})$ dissolved in distilled water and stirred in another glass beaker with the help of a magnetic stirrer at $25^{\circ} \mathrm{C}$. The basic solution $(\mathrm{NaOH})$ was slowly added (3 drops in minute) to the $\mathrm{ZnCl}_{2}$ solution under constant stirring until the $\mathrm{pH}$ equal 8 then precipitation occurred. Then washed with distilled water (about 5 times) and then with ethanol (2 times) and then we dry the precipitate inside the oven at $200^{\circ} \mathrm{C}$ for $90 \mathrm{~min}$.

1. $\mathrm{ZnCl}_{2}+2 \mathrm{NaOH} \rightarrow \mathrm{Zn}(\mathrm{OH})_{2}+2 \mathrm{NaCl}$

2. $\mathrm{Zn}(\mathrm{OH})_{2} \rightarrow \mathrm{ZnO}+\mathrm{H}_{2} \mathrm{O}$

The overall equation is:

$$
\mathrm{ZnCl}_{2}+2 \mathrm{NaOH} \rightarrow \mathrm{ZnO}+\mathrm{H}_{2} \mathrm{O}+2 \mathrm{NaCl}
$$

\subsection{Solution preparation to deposited thin film:}

IZO thin films at different compositions In: $\mathrm{Zn} \mathrm{(80:20} \mathrm{and} \mathrm{60:40} \mathrm{mole} \mathrm{ratio)} \mathrm{were}$ deposited by the sol gel dip coating way adopting this procedure. $\mathrm{ZnO}$ and $\operatorname{In}_{2} \mathrm{O}_{3}$ oxides were dissolved in mixed solution of poly ethylene glycol (2-4 drops) and distilled water. The two solutions were mixed $\left(\right.$ at $60^{\circ} \mathrm{C}$ ) and stirred for 2 hours, as shown in Table (1). The films were obtained by dipping quartz glasses in $\mathrm{ZnO} / \mathrm{In}_{2} \mathrm{O}_{3}$ - solution and then they were dried at $200^{\circ} \mathrm{C}$.

Table (1)

The amount of $\mathrm{ZnO}$ and $\mathrm{In}_{2} \mathrm{O}_{3}$ and their mole ratio.

\begin{tabular}{||c|c||c||c|}
\hline $\begin{array}{c}\mathbf{I n}_{2} \mathbf{O}_{3} \\
\text { solution } \\
\text { mole }\end{array}$ & $\begin{array}{c}\mathbf{Z n O} \\
\text { solution } \\
\text { mole }\end{array}$ & $\begin{array}{c}\text { Mixture } \\
\text { solution } \\
(\mathbf{m l})\end{array}$ & $\begin{array}{c}\text { Ratio\% } \\
\left(\mathbf{I n}_{2} \mathbf{O}_{3} / \mathbf{Z n O}\right)\end{array}$ \\
\hline \hline 0.80 & 0.20 & 20 & 80 \\
\hline 0.60 & 0.40 & 20 & 60 \\
\hline
\end{tabular}

The thin films forming via deposited by dip coating technique. The quartz substrate is immersed in the dispersion and then withdrawn at a constant speed. The substrate stayed in the solution (about $30 \mathrm{sec}$ ) and then dried for 5 minute at $100{ }^{\circ} \mathrm{C}$. The thickness of the film can be controlled by the number of the dip, the number of dipping about (10- 25 dip).

\section{Results and Discussions \\ 3.1 Analysis of XRD of particles:}

For characterization of indium oxide, X-ray diffractometer using $\mathrm{CuK} \alpha$ radiation $(\lambda=1.54050$ A). XRD spectra were recorded by scanning $2 \theta$ in the range $(20-60) \mathrm{deg}$. $\mathrm{X}$-ray diffraction measurement has been done and compared with the JCPDS cards no. (211272) for $\operatorname{In}_{2} \mathrm{O}_{3}$. X-ray diffraction was used to determine the phase structure of the assynthesized $\operatorname{In}(\mathrm{OH})_{3}$ and its thermally manufactured products $\left(\mathrm{In}_{2} \mathrm{O}_{3}\right)$. Fig.(1-a) show the diffraction patterns of $\mathrm{In}(\mathrm{OH})_{3}$ at $\left(200^{\circ} \mathrm{C}\right)$ are occurred at $2 \theta$ values of approximately (22.4493, 31.9450, 51.4601 and 56.5230 ) corresponding to (200), (220), (420) and (422) respectively. All the diffraction peaks of these XRD patterns could be perfectly indexed to those of body-centre cubic In $(\mathrm{OH})_{3}$ according to the (JCPDS Card No. 01-076-1463). Whereas at $\left(400^{\circ} \mathrm{C}\right)$ four diffraction plans appears (211), (222), (400) and (440) located at $(2 \Theta=21.5644,30.6921,35.5649$ and $\left.51.0914^{\circ}\right)$ respectively, as shown in Fig.(1- b), that are close to the values of the reference data JCPDS card (no: 06-0416). All the spectra show that particles are polycrystalline with a cubic structure and the final products exhibited excellent crystallinity. By the heat treatment to the atoms the defects and the grain boundaries in the $\operatorname{In}_{2} \mathrm{O}_{3}$ decreasing and this lead to decreases (FWHM) of the reflection peaks and the crystallite size of the particles increases, as shown in Table (2), this contribute to the improving the crystallinity of particles [10]. The lattice constant close calculated values to the standard lattice constant of $\operatorname{In}(\mathrm{OH})_{3}$ and $\mathrm{In}_{2} \mathrm{O}_{3} \quad\left(\mathrm{a}_{0}=7.974\right.$ and $\mathrm{a}_{\mathrm{o}}=10.117 \quad \mathrm{~A}^{\mathrm{o}}$ respectively). 

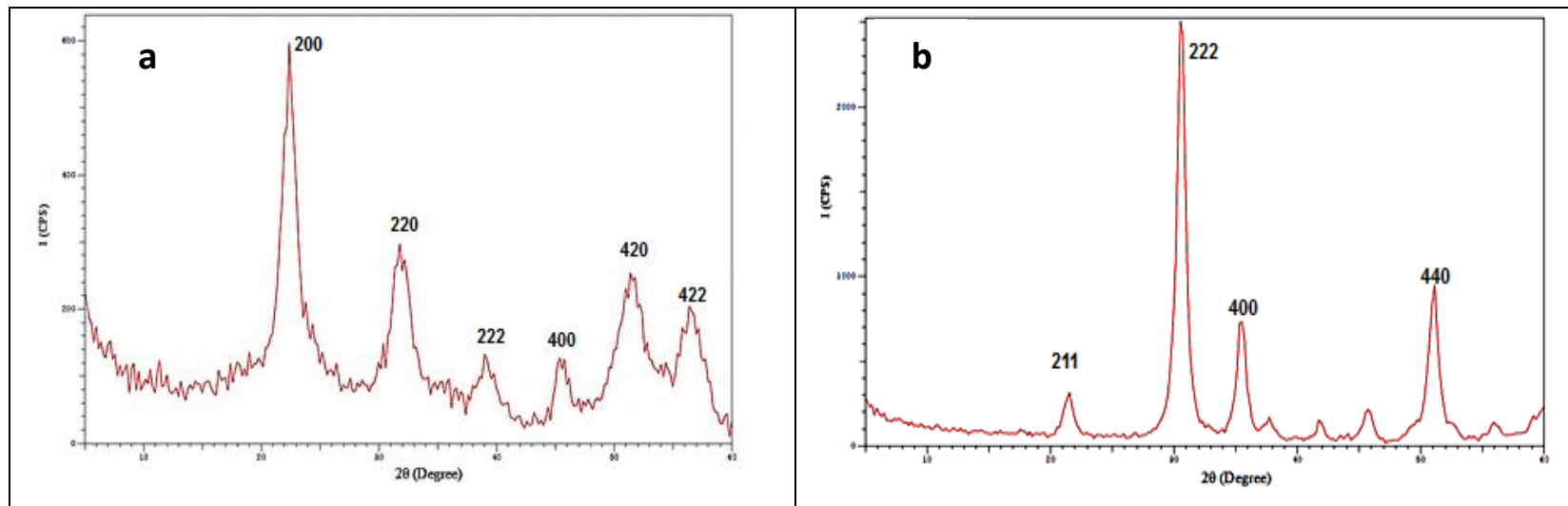

Fig.(1): XRD patterns of the particles (A): $\operatorname{In}(\mathrm{OH})_{3}$ at $200{ }^{\circ} \mathrm{C}(\mathrm{B}): \mathrm{In}_{2} \mathrm{O}_{3}$ at $400{ }^{\circ} \mathrm{C}$.

Table (2)

The $X R D$ results of indium oxide particles.

\begin{tabular}{|c||c||c||c|c||c||c||}
\hline $\begin{array}{c}\text { Annealing } \\
\text { Temp. 90min }\end{array}$ & $\begin{array}{c}\mathbf{2 \theta} \\
(\mathbf{d e g})\end{array}$ & Hkl & $\begin{array}{c}\text { FWHM } \\
(\boldsymbol{\beta}) \\
(\mathbf{d e g})\end{array}$ & $\begin{array}{c}\text { Grain } \\
\text { Size } \\
\left(\mathbf{A}^{\circ}\right)\end{array}$ & $\begin{array}{c}\text { Lattice } \\
\text { constant } \\
\left(\mathbf{A}^{\circ}\right)\end{array}$ & $\mathbf{D}^{\mathbf{(}}\left(\mathbf{A}^{\circ}\right)$ \\
\hline \hline \multirow{3}{*}{$\begin{array}{c}200{ }^{\circ} \mathrm{C} \\
\text { As-prepared }\end{array}$} & 22.4493 & 200 & 1.5794 & 51.280326 & 7.914459 & 3.95722 \\
\cline { 2 - 7 } & 31.945 & 220 & 1.9994 & 41.328914 & 7.917615 & 2.79929 \\
\cline { 2 - 7 } & 51.460 & 420 & 2.6985 & 32.679875 & 7.935119 & 1.77434 \\
\cline { 2 - 7 } & 56.5230 & 422 & 2.42340 & 37.218146 & 7.969824 & 1.62683 \\
\hline \multirow{3}{*}{$400{ }^{\circ} \mathrm{C}$} & 21.5644 & 211 & 0.9438 & 85.68619 & 10.08595 & 4.11757 \\
\cline { 2 - 7 } & 30.6921 & 222 & 0.8439 & 97.61838 & 10.08280 & 2.91065 \\
\cline { 2 - 7 } & 35.5649 & 400 & 0.8732 & 95.54383 & 10.08894 & 2.52223 \\
\cline { 2 - 7 } & 51.0914 & 440 & 0.9498 & 92.70432 & 10.10473 & 1.78282 \\
\hline \hline
\end{tabular}

Figs. (2 a and b) show the X-ray diffraction patterns of indium zinc oxide powder annealed at $400^{\circ} \mathrm{C}$ and at different compositions (In: $\mathrm{Zn}=80: 20$ and 60:40 mole). At concentration $(20 \%$ mole $\mathrm{ZnO})$. The strongest peaks appeared approximately at $2 \theta(21.625$, $30.731, \quad 35.567$ and $\left.51.174^{\circ}\right)$ which are corresponding to (211), (222), (400) and (440) respectively. When at concentration (40\% mole $\mathrm{ZnO}$ ) four different located peak appears at $\left(2 \Theta=21.695,30.774,35.821\right.$ and $\left.51.187^{\circ}\right)$ which are corresponding to (211), (222), (400) and (440), respectively.

None of the spectra indicated any characteristic peaks of $\mathrm{ZnO}$, which means that the zinc atoms were doped substitutionally into the $\mathrm{In}_{2} \mathrm{O}_{3}$ lattice and this agree with reference [11]. The results of IZO particles shown high intensity in plane (222), and the particles have polycrystalline structure. Addition the $\mathrm{ZnO}$ into $\mathrm{In}_{2} \mathrm{O}_{3}$ particles lead to decreases the intensity of peak (222), and increases the
FWHM (decreases the grain size), either the lattice parameter decreases, as shown in Table (3). 

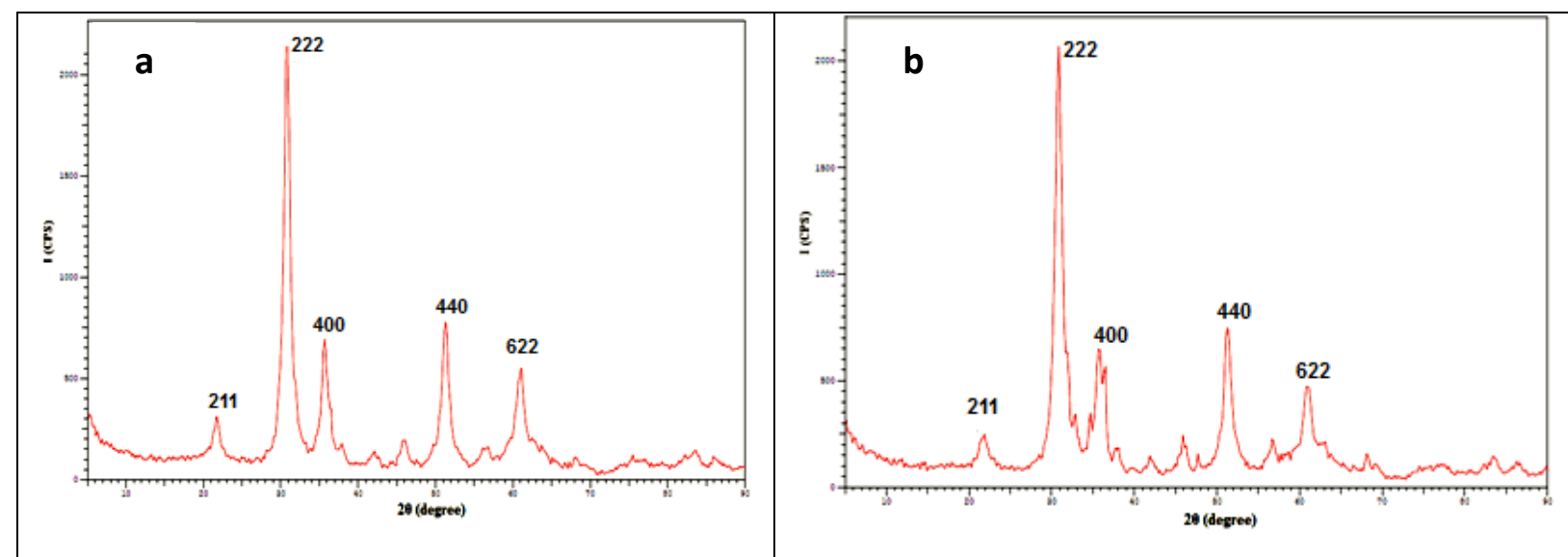

Fig. (2): XRD pattern of: (a) IZO 80\% mole, (b) IZO 60\% mole annealed at $400{ }^{\circ} \mathrm{C}$.

Table (3)

The obtained results of the XDR for IZO particles at 80, $60 \%$ mole at annealing temperature $400^{\circ} \mathrm{C}$.

\begin{tabular}{|c|c|c|c|c|c|c|}
\hline Samples & $2 \theta$ (deg) & Hkl & $\begin{array}{c}\text { FWHM( } \beta) \\
(\operatorname{deg})\end{array}$ & $\begin{array}{c}\text { Grain Size } \\
\left(\mathrm{A}^{\circ}\right) \\
\end{array}$ & $\begin{array}{c}\text { Lattice } \\
\text { constant }\left(\mathrm{A}^{\circ}\right)\end{array}$ & $\mathbf{D}\left(\mathbf{A}^{\circ}\right)$ \\
\hline \multirow{4}{*}{$\begin{array}{c}\mathrm{ZnO} \\
20 \% \\
\text { Mole }\end{array}$} & 21.6255 & 211 & 1.0342 & 78.20426 & 10.05779 & 4.106078 \\
\hline & 30.7315 & 222 & 0.9559 & 86.18885 & 10.07019 & 2.907014 \\
\hline & 35.6574 & 400 & 1.0836 & 77.01227 & 10.06361 & 2.515904 \\
\hline & 51.0946 & 440 & 1.0073 & 87.442901 & 10.08937 & 1.783566 \\
\hline \multirow{4}{*}{$\begin{array}{l}\mathrm{ZnO} \\
40 \% \\
\text { Mole }\end{array}$} & 21.6915 & 211 & 1.2667 & 63.85707 & 10.02756 & 4.09373 \\
\hline & 30.7742 & 222 & 1.1453 & 71.94304 & 10.05655 & 2.903078 \\
\hline & 35.8212 & 400 & 1.5056 & 55.45229 & 10.01909 & 2.504774 \\
\hline & 51.187 & 440 & 1.112 & 79.21378 & 10.08713 & 1.783170 \\
\hline
\end{tabular}

\subsection{Fourier Transform Infrared Spectroscopy (FTIR)}

FTIR is a powerful tool for the identification of the molecular mechanism associated with the formation of the oxide.

FTIR spectrum of the prepared material $\left(\mathrm{In}(\mathrm{OH})_{3}\right)$ show a large absorption band around $3500 \mathrm{~cm}^{-1}$ characteristic of $\mathrm{OH}$ stretching absorbed water, because of the difficulty of removing the water residue completely [12]. Two main intense peaks centered at 775 and $503 \mathrm{~cm}^{-1}$ were observed, which is characteristic of the $\mathrm{In}-\mathrm{O}(\mathrm{H})$ and $\mathrm{In}-\mathrm{O}$ stretching respectively. The most prominent absorption bands detected after thermal annealing at $\left(400^{\circ} \mathrm{C}\right)$ are quite similar, with the main absorption bands at $3420 \mathrm{~cm}^{-1}$ due to water and low wave number bands (601, $567,540,491$ and $457 \mathrm{~cm}^{-1}$ ) which are due to the indium-oxygen bond. These results are in general agreement with those of thermal analysis [13].
The FTIR peaks spectra near to 3400 and near to $1630 \mathrm{~cm}^{-1}$ of the IZO $(20 \%)$ as prepared and annealing in $400{ }^{\circ} \mathrm{C}$ respectively, correspond to stretching vibration and bending of $\mathrm{O}-\mathrm{H}$ band respectively. The absorption peak of $\mathrm{Zn}-\mathrm{OH}$ is near to $1145 \mathrm{~cm}^{-1}$, while peaks at 788 and between $422-599 \mathrm{~cm}^{-1}$ corresponding to (In-OH) and In-O stretching respectively.

\subsection{The Results AFM of $\mathrm{In}_{2} \mathrm{O}_{3}$ and IZO Particles}

The surface morphology of $\operatorname{In}_{2} \mathrm{O}_{3}$ particles preparation by sol gel method (annealed at $400^{\circ} \mathrm{C}$ ) was analyzed by using atomic force microscope. Fig.(3) show images 3D and the granularity cumulation distribution chart of $\mathrm{In}_{2} \mathrm{O}_{3}$ particles annealed at $400^{\circ} \mathrm{C}$. The average grain size was $(96.6 \mathrm{~nm})$. 


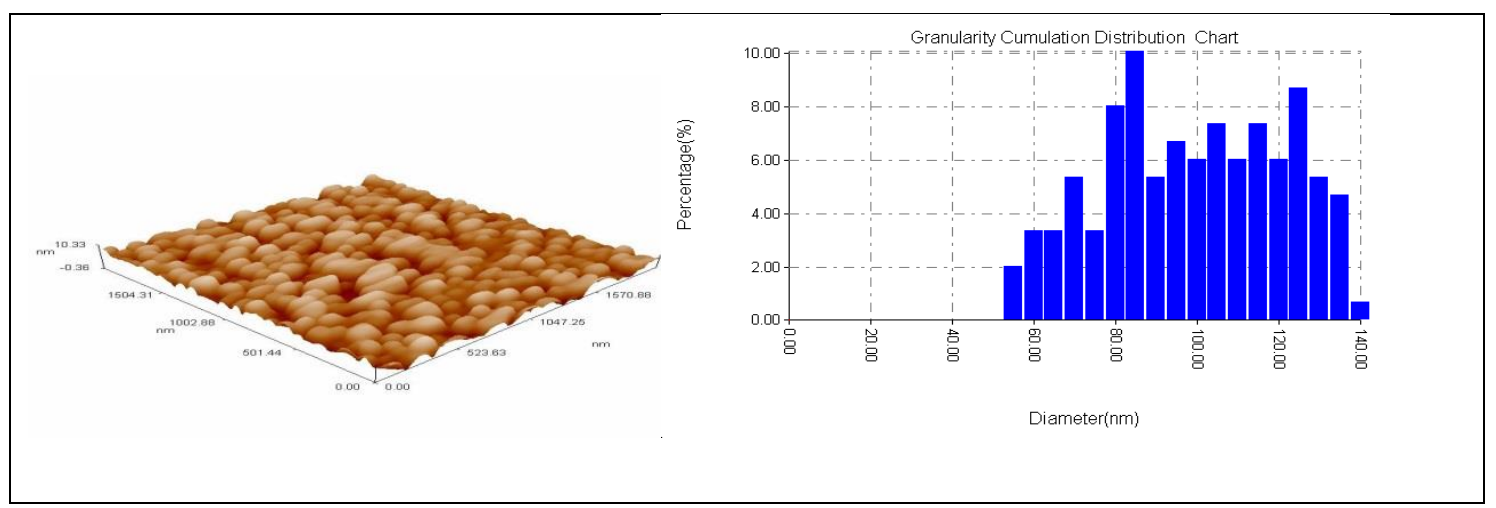

Fig.(3): AFM images 3D and B- granularity cumulation distribution chart of $\mathrm{In}_{2} \mathrm{O}_{3}$ annealed at $400{ }^{\circ} \mathrm{C}$.

The AFM images 3D and the granularity cumulation distribution chart of IZO $(20 \%$ and $40 \%$ mole $\mathrm{ZnO}$ ) annealed at $400{ }^{\circ} \mathrm{C}$ are shown in Figs.(4- $a$ and $b$ ). The average grain size of IZO is about $(82.72-90.04 \mathrm{~nm})$. The AFM results IZO shows that has a smaller particles diameter compared with $\operatorname{In}_{2} \mathrm{O}_{3}$ pure, this may due to rearrangement of atom and reduce the vacancy defect, also shows a uniform grain size and a smooth surface and the surface roughness is much smaller compared with $\mathrm{In}_{2} \mathrm{O}_{3}$ the geometry of the surface has a high degree of regularity these results agrees with reference [14].

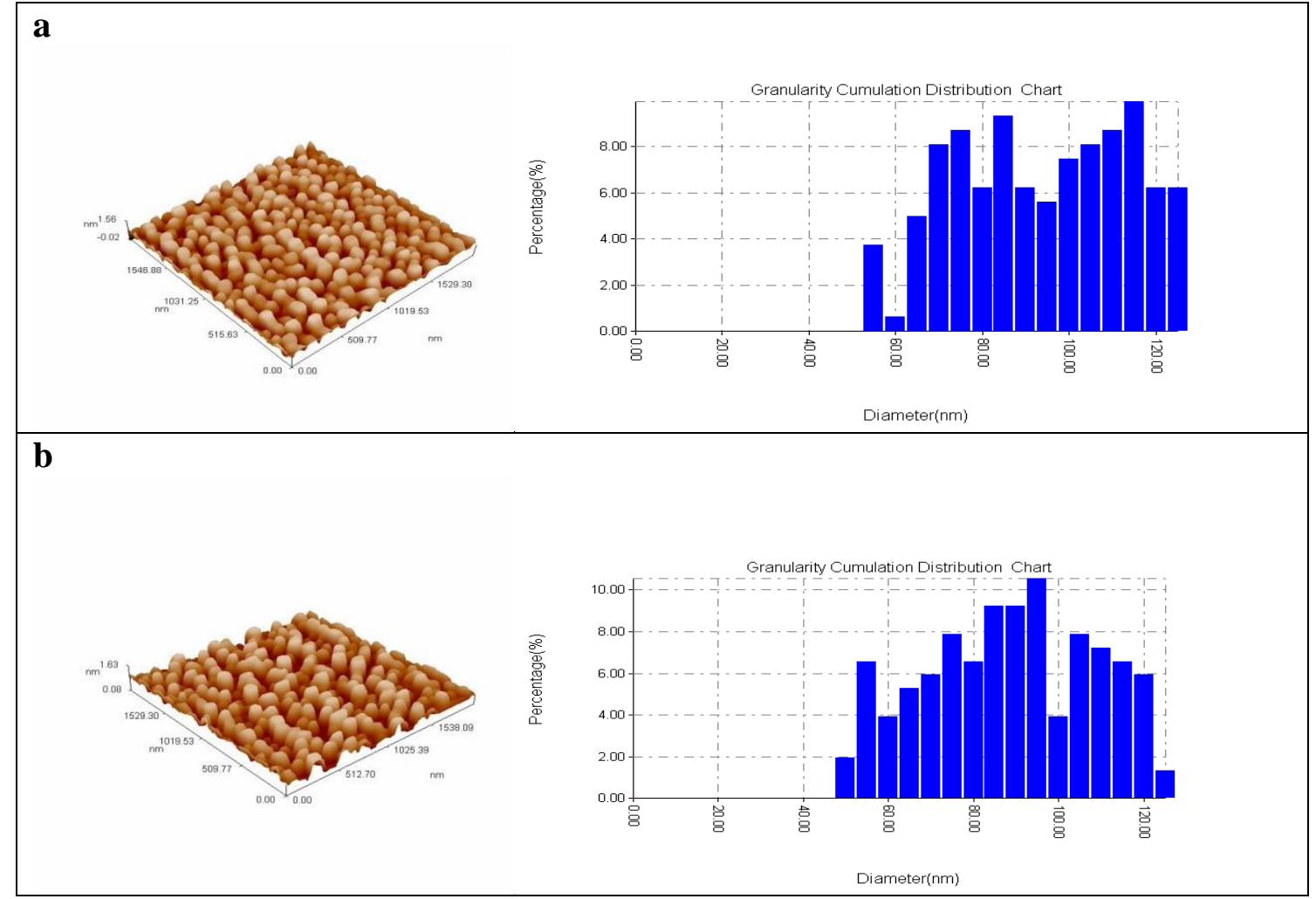

Fig.(4): AFM images 3D and Granularity cumulation distribution chart of IZO particles (a) IZO $20 \%$ (b) IZO $40 \%$ annealed at $400{ }^{\circ} \mathrm{C}$.

\subsection{Optical Properties}

Optical transmission data is more important in evaluating the optical properties of metallic oxides thin films. High transparency in the visible region is required in application for optoelectronic devices [15]. 


\subsubsection{Transmittance Results of ( $\operatorname{In}_{2} \mathrm{O}_{3}$ and IZO)}

The effect the different annealing temperature $\left(200\right.$ and $\left.400^{\circ} \mathrm{C}\right)$ for $(90 \mathrm{~min})$ on $\mathrm{In}_{2} \mathrm{O}_{3}$ thin films is shown in Fig.(5-a), that the films have high transmission reach to $80 \%$. With the increasing annealing temperature the transmittance is slightly increased within this spectral range, this result agrees with reference [16].

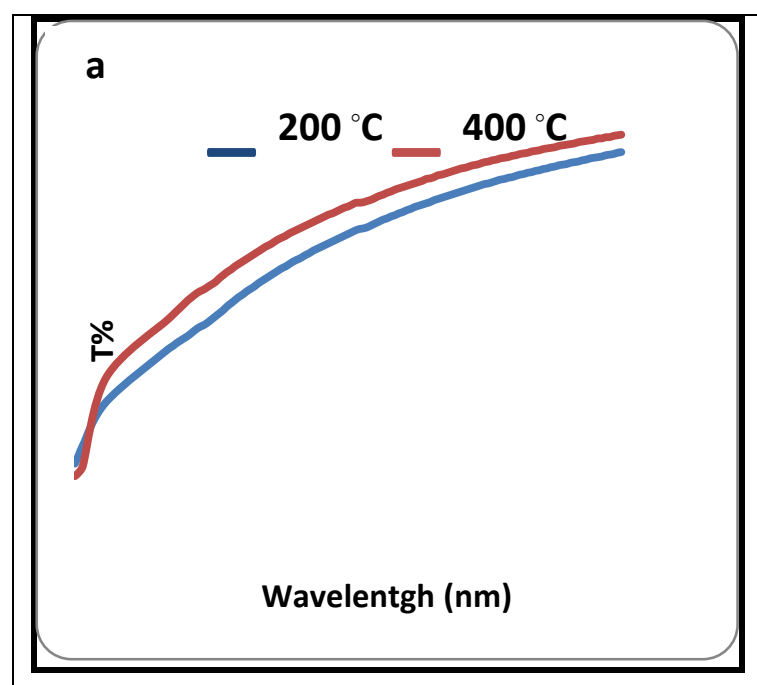

The optical transmittance spectra of for IZO at different compositions ( $\mathrm{In}: \mathrm{Zn}=80: 20$ and $60: 40$ mole) and were annealed at $400^{\circ} \mathrm{C}$. The Fig.(5-b) show the samples are highly transparent in the visible region of films IZO (20 and $40 \%)$ is about $(71.1-77 \%)$, this result agrees with reference [14].

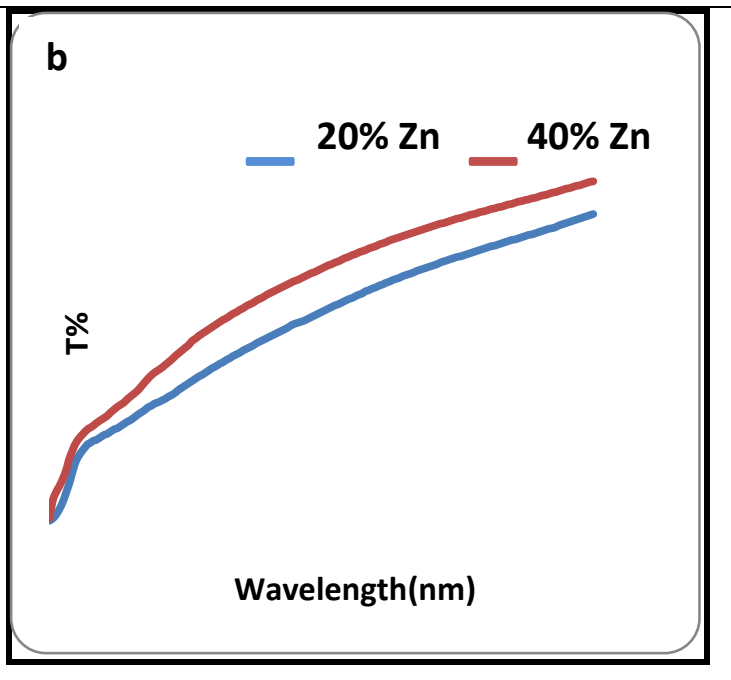

Fig.(5): $U$ V-VIS transmittance spectra of $\mathrm{In}_{2} \mathrm{O}_{3}$ thin films: (a) at different annealing temperature $\left(200\right.$ and $\left.400{ }^{\circ} \mathrm{C}\right),(\mathrm{b})$ at different compositions (20 and 40\%mole) with Zinc Oxide.

\subsubsection{Energy Band Gap of ( $\operatorname{In}_{2} \mathrm{O}_{3}$ and IZO)}

The band gap of $\mathrm{In}_{2} \mathrm{O}_{3}$ thin films was calculated by using transmittance spectrum of them. Band gap variation of $\operatorname{In}_{2} \mathrm{O}_{3}$ thin films with respect to annealing temperature were further increased with increased annealing temperature as shown in Figs.(6- a and b), That shift is due to increment in number of carrier increases which leads to filling the lowest energy state in the conduction band.
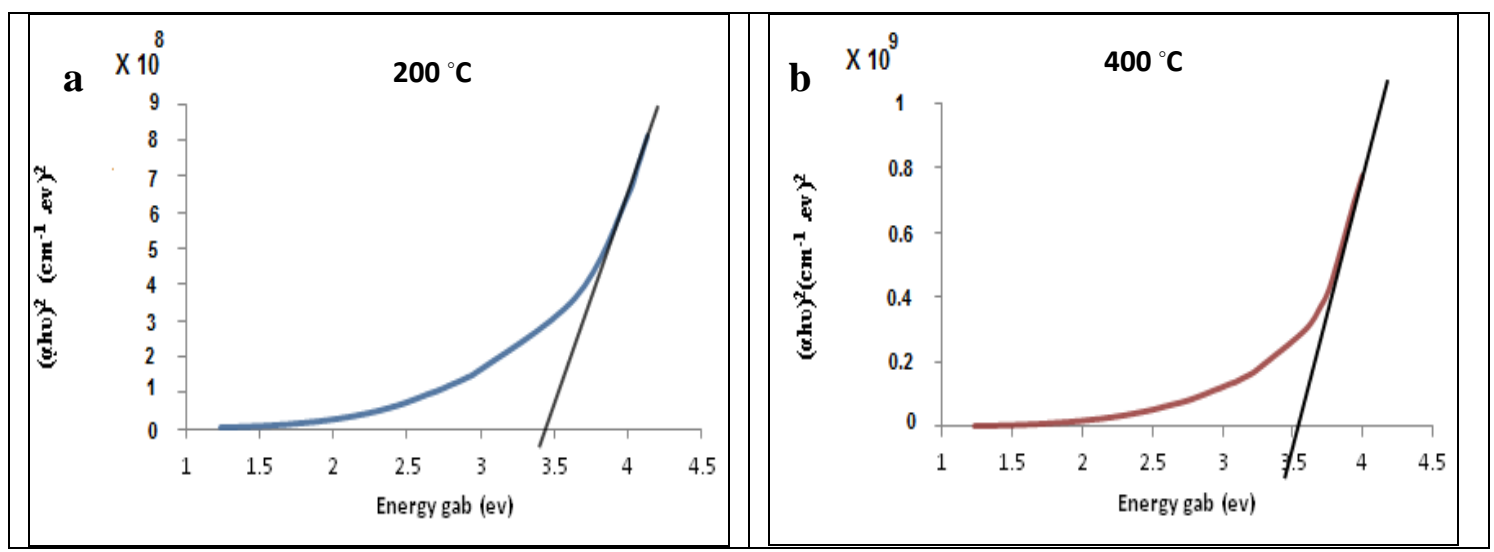

Fig.(6): The Band gab of $\operatorname{In}_{2} \mathrm{O}_{3}$ thin films annealed at (a) $200^{\circ} \mathrm{C}$, (b) at $400{ }^{\circ} \mathrm{C}$. 
The direct band gab values of IZO thin films at different compositions (In: $Z n=80: 20$ and 60:40 mole). When the additive contained of $(\mathrm{ZnO})$ into $\mathrm{In}_{2} \mathrm{O}_{3}$ increases the band gab value decreases, as shown in Figs.(7- a and b). This could be linked to defects increase with decreasing in grain size because band gap value related to the crystalline of thin film also this my due to formation of sub band between the band gap and conduction band.
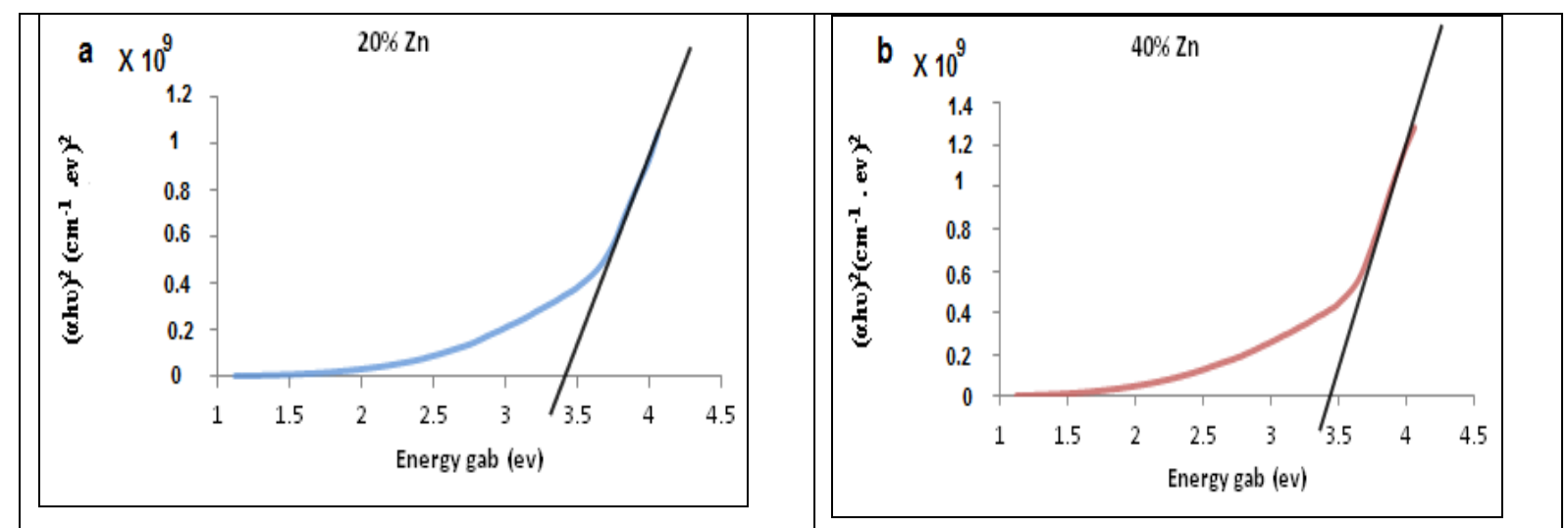

Fig.(7): The Band gab of IZO thin film (a) $20 \%$ and (b) $44 \%$ annealed at $400{ }^{\circ} \mathrm{C}$.

Table (4)

Experimental results of $\mathrm{In}_{2} \mathrm{O}_{3}$ and IZO thin films.

\begin{tabular}{||c||c||c|}
\hline \multicolumn{1}{|c||}{ Different condition } & \multicolumn{2}{c|}{ Eg (ev) } \\
\hline \hline $\mathrm{In}_{2} \mathrm{O}_{3} / 200{ }^{\circ} \mathrm{C}$ & Pure & 3.4 \\
\hline \hline $\mathrm{In}_{2} \mathrm{O}_{3} / 400{ }^{\circ} \mathrm{C}$ & Pure & 3.55 \\
\hline \hline $\begin{array}{c}\text { Concentration zinc } \\
\text { oxide }(\mathrm{ZnO})\end{array}$ & $20 \%$ & 3.37 \\
\cline { 2 - 3 } & $40 \%$ & 3.4 \\
\hline \hline
\end{tabular}

\subsection{Hall Measurements of $\left(\operatorname{In}_{2} \mathrm{O}_{3}\right.$ and IZO)}

The thin films annealed at different temperature $\left(200\right.$ and $\left.400^{\circ} \mathrm{C}\right)$ for $90 \mathrm{~min}$, have been measured, the results evident to that the indium oxide have conductivity (n-type), on the other hand we notice the carrier concentration increases versus increasing annealing temperature, this is may be due to the presence of In interstitials and the partial extinction of the doubly charged oxygen vacancies. Whereas the Hall mobility and Hall coefficient decreases with increasing temperature as shown in Table (5). The decreasing of Hall mobilities can be explained by scattering in semiconductors. the measurements of indium zinc oxide at compositions (In: $\mathrm{Zn}=80: 20$ and 60:40) show increases in the electrical conductivity value, and also increases in the values of charge carrier whereas the values of the hall mobility decreases, and hall coefficient value decreases, The mobility decreases with increasing the additive contained of $(\mathrm{ZnO})$ into $\mathrm{In}_{2} \mathrm{O}_{3}$ thin films, this may be attributed to increase of ionized scattering center and decreasing in the average of the grain size with increasing the additive concentration into $\mathrm{In}_{2} \mathrm{O}_{3}$ the films Therefore the additive concentration in $\mathrm{In}_{2} \mathrm{O}_{3}$ thin films plays a vital role in determining its electrical properties [17]. 
Table (5)

The obtained results of Hall measurement of $\mathrm{In}_{2} \mathrm{O}_{3}$ and IZO.

\begin{tabular}{||c||c||c||c||c||}
\hline Sample Thin & $\begin{array}{c}\text { RH } \\
\left(\mathbf{c m}^{\mathbf{3} /} \mathbf{C}\right)\end{array}$ & $\begin{array}{c}\text { Resistivity } \\
(\boldsymbol{\Omega} . \mathbf{c m})\end{array}$ & $\begin{array}{c}\mu \mathbf{H} \\
\left(\mathbf{c m}^{2} / \mathbf{v . s}\right)\end{array}$ & $\begin{array}{c}\text { Carrier } \\
\text { concentration }_{(\mathbf{c m})} \mathbf{- n}^{-3}\end{array}$ \\
\hline \hline $\mathrm{In}_{2} \mathrm{O}_{3} / 200^{\circ} \mathrm{C}$ & $1.1^{*} 10^{7}$ & $1.52^{*} 10^{5}$ & $7.3^{*} 10$ & $5.5^{*} 10^{11}$ \\
\hline \hline $\mathrm{In}_{2} \mathrm{O}_{3} / 400^{\circ} \mathrm{C}$ & $1.5^{*} 10^{6}$ & $4.5^{*} 10^{4}$ & $3.4^{*} 10$ & $4.05^{*} 10^{12}$ \\
\hline \hline $\mathrm{In}-\mathrm{Zn}=80-20$ & $3.2^{*} 10^{5}$ & $2.8^{*} 10^{5}$ & 1.11 & $1.9^{*} 10^{13}$ \\
\hline \hline $\mathrm{In}-\mathrm{Zn}=60-40$ & $3.02^{*} 10^{3}$ & $5.8^{*} 10$ & $5.2^{*} 10$ & $2.06^{*} 10^{15}$ \\
\hline
\end{tabular}

\subsection{Conclusions}

The results of XRD evident to that the $\mathrm{In}_{2} \mathrm{O}_{3}$ particles have polycrystalline structure with strongest peak (222) and good crystallinity which increasing with increases of annealing temperature. Either the IZO particles have diffraction peak slighter than $\mathrm{In}_{2} \mathrm{O}_{3}$ pure. The transmittance spectra of $\operatorname{In}_{2} \mathrm{O}_{3}$ thin film reach to $80 \%$ at $400^{\circ} \mathrm{C}$. Energy band gap of $\mathrm{In}_{2} \mathrm{O}_{3}$ thin films excess with increasing of annealing temperature, while become less with increases the additive content of $(\mathrm{ZnO})$. The results of Hall measurements show that $\mathrm{In}_{2} \mathrm{O}_{3}$ and IZO thin films have a negative Hall coefficient $(\mathrm{RH})$ values which confirm that films are (n-type).

\section{References}

[1] Hong J. and Han J. I., Fabrication of indium tin oxide (ITO) thin film with pretreated sol coating, J. Korean Phys. Soc., 45(3), 634-637, 2004.

[2] Chopra K.L., Major S., Pandya D.K., Transparent conductors-A status review. Thin Solid Films. 102(1), 1-46, 1983.

[3] Lewis B.G., Paine D.C., Applications and Processing of Transparent Conducting Oxides. MRS Bull. 25(8), 22-27, 2000.

[4] Wang A., Babcock J. R., Edleman N. L., Metz A. W., Lane M. A., Asahi A., Dravid V. A., Kannewurf C. R., Feeeman A. J. and Marks T. J., Indium-cadmium-oxide films having exceptional electrical conductivity and optical transparency: Clues for optimizing transparent conduct-ors. Proc Natl. Acad. Sci. U S A. 98(13), 7113-7116, 2001.

[5] Tominaga K., Takao T., Fukushima A., Moriga T., and Nakabayashi I., Amorphous $\mathrm{ZnO}-\mathrm{In}_{2} \mathrm{O}_{3}$ transparent conductive films by simultaneous sputtering method of $\mathrm{ZnO}$ and
$\mathrm{In}_{2} \mathrm{O}_{3}$ targets. Original Research Article Vacuum, 66(3-4), 505-509, 2002.

[6] Minami T., Kakumu T., Takeda Y., and Takata S., High transparent and conductive $\mathrm{ZnO}-\mathrm{In}_{2} \mathrm{O}_{3}$ thin films prepared by d. c. magnetron sputtering. Thin Solid Films. 1, 290- 291, 1996.

[7] Minami T., Kakumu T., Takeda Y. and Takeda A., New transparent conducting $\mathrm{ZnO}-\mathrm{In}_{2} \mathrm{O}_{3}-\mathrm{SnO}_{2}$ thin films prepared by magnetron sputtering. Thin Solid Films, 317, 326-331, 1998.

[8] Naghavi N., Marcel C., Dupont L. Guery C., Leriche J. B. and Tarascon J. M., Structural and physical characterisation of transparent conducting pulsed laser deposited In2O3-ZnOthin films. J. Mater. Chem. 10, 2315-2319, 2000.

[9] Plocek J., Hutlova A., Niznansky D., Buršik, J., Rehspringer, J.L. and Mička, Z., Preparation of $\mathrm{CuFe}_{2} \mathrm{O}_{4} / \mathrm{SiO}_{2}$ nanocomposite by the sol-gel method, Materials Science-Poland, 23(3), 2005.

[10] Solieman A. Effect of sintering temperature on the structural, optical and electronical prpperities of sol-gel derived indium oxide thin films. J. Sol-gel Science and Technology, 60, 48-57, 2011.

[11] Mohammad H. and Nasrin T. The Effect of Annealing on Structural, Optical and Electrical Properties of Nanostructure Tin Doped Indium Oxide Thin Films. Acta Chim, 52, 53-59, 2005.

[12] Guodong L. Synthesis, Characterization of In2O3 Nanocrystals and Their Photoluminescence Property. Int. J. Electrochem. Sci., 6, 2162 - 2170, 2011.

[13] Souza E.C.C., Rey J.F.Q., and Muccillo E.N.S. Synthesis and characterization of spherical and narrow size distribution indium oxide nanoparticles. Applied Surface Science, 255, 3779-3783, 2009. 
[14] Mokhtar H., Faouzi G. and Lassaad E. M., Characterization of ITO Thin Films Prepared by Sol-gel Spin-Coating Technique. Sensors \& Transducers, 27, 198-201, 2014.

[15] Viji V R, kumar K S, Stela M., and et al. Indian Journal of Pure and Applied physics, 43, 368-371, 2005.

[16] Kraini M., Bouguila N., Halidou I., Abdelmajid T., and Alaya S., Properties of In2O3 films obtained by thermal oxidation of sprayed In2S3. Elsevier, 16, 1388-1396, 2013.

[17] Yvonne G. and Andreas K., Electronic and Chemical Properties of Tin-Doped Indium Oxide (ITO) Surfaces and ITO/ZnPc Interfaces Studied In-situ by Photoelectron Spectroscopy. J. Phys. Chem. 110, 4793-4801, 2006.

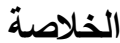

تم تحضير جسيمات اوكسيد الأنديوم وجسيمات متراكبة

من اوكسيدي الأنديوم/خارصين (IZO) بواسطة طريقة محلول- جيلاتين ومن ثم رسبت على ركائز من الكوارتز بواسطة تقنية التغطية بالغمر • لدنت النماذج بدرجات حرارية

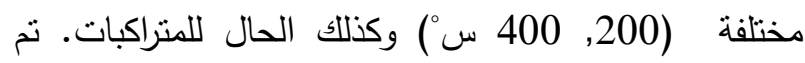
تنخص التركيب البلوري وهيئة السطح للجسيمات بواسطة

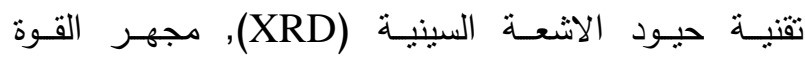
الذرية (AFM) وقياسات الأشعة تحت الحمراء (FT-IR). اظهرت نتائج XRD و AFM تتاقص الحجم الحبيبي للمتراكب وتحسن الخصائص البصرية والكهربائية مع زيادة اضافة اوكسيد الخارصين. بينت قياسات تاثير الفجوة ان

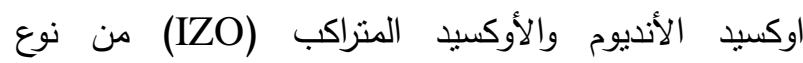
.(n-type) 